\title{
BOVINE MAMMARY GLAND DURING THE DRY PERIOD: 1. HISTOLOGICAL AND ULTRASTRUCTURAL CHANGES
}

\author{
A. I. M. El-Sayed ${ }^{1}$, A. S. M. Soliman ${ }^{1}$, A. M. El-Gaafarawy ${ }^{2}$ and M. A. E. \\ $\mathrm{Ali}^{2}$ \\ 1- Animal Production Department, Faculty of Agriculture, Benha University, 2- Animal \\ Production Research Institute, Agriculture Research Center, Ministry of Agriculture
}

\section{SUMMARY}

A total number of 16 pregnant Friesian cows were divided according to the dry period length into two groups. The first included cows $(n=8)$ with dry period more than 60 days, while the second group included cows $(n=8)$ with dry period less than 45 days.

Histological changes during involution period indicated marked shifts in the secretory activity of the gland during the active involution phase as evidenced by a reduction in alveolar luminal area with a concomitant increase in connective tissue area. Cytoplasmic organelles declined in the involuting cells, particularly the rough endoplasmic reticulum (RER), ribosomes, Golgi apparatus, and also the secretory vesicles. Despite the apparent reduction of the protein synthesis and secretion pathway associated with milk proteins, the involuting epithelial cells maintained intact cellular organelles which involved in metabolic and secretory function. Ribosomes and segments of RER were present at all stages of involution, as were mitochondria and microvilli. Invading macrophages have been implicated in removal of luminal milk fat globules in involuting mammary tissue and also may be involved in removal of cellular debris. The structure of alveoli at steady state involution phase resembled the solid mass of cells. The structure of bovine mammary tissue and the composition of mammary secretions remained relatively constant. The involution of bovine mammary tissue does not involve extensive detachment of mammary epithelial cells from the basement membrane as occurs in rodents. During the redevelopment and colostrogenesis phase, increased synthetic and secretory activity were apparent by an increase areas of epithelium and lumen and a decrease area of connective tissue. Expansion of alveolar lumina area resulted in a concomitant compression of surrounding connective tissue area. As parturition approached, fully active cells became more numerous, the cell cytoplasm contained abundant RER, well-developed Golgi apparatus, and numerous mitochondria. Although the progression of ultrastructural changes in alveolar epithelial cells were consistent between the cows with the long dry period and those with the short dry period, the obtained results suggest that the rate at which this progression occurred was faster in the cows receiving the short dry period. Ultrastructural changes of cow mammary tissue suggest that a mammary involution as it relates to the epithelia, occurs as an organized and controlled process that apparently leads to minor loss of epithelial cells. In addition, the present results confirmed that the dry period is important for replacing senescent mammary epithelial cells and increasing the epithelial component of the gland prior to the next lactation.

Keywords: cows, dry period, mammary gland, histology, ultrastructure

Issued by The Egyptian Society of Animal Production 


\section{INTRODUCTION}

Despite the importance of the dry period, little is known about the extent of involution, growth, and differentiation that occurs in the bovine mammary gland tissue during this period. Following cessation of milking or weaning of the young, involution of the mammary glands occurs, a process that has been extensively investigated with rodents. However, data generated for other species may not be easily extrapolated to the cow. Histological investigations (Holst et al., 1987; Sordillo and Nickerson, 1988; Hurley, 1989; and Akers et al., 1990) suggest that mammary involution in cattle is slower and far less extensive than that in rodents. In sharp contrast to the situation in most species, dairy cows are typically pregnant when milk removal ceases. Consequently, mammary involution during the dry period is promoted by milk stasis but is opposed by the mammogenic and lactogenic effects of pregnancy (Capuco et al., 1997).

The objectives of this study were to evaluate and interpret the histological and cytological changes that occur in the mammary gland tissues during the different stages of the dry period in Friesian cows. Also, to determine the impact of these changes on the activity of mammary gland during the prepartum period.

\section{MATERIALS AND METHODS}

The field study of this experiment was carried out at Sakha Experimental Station, belonged to Animal Production Research Institute, Agriculture Research Center, Ministry of Agriculture, Dokki, Giza, Egypt. The field work lasted for eight months starting from November, 2004.

Histological study was executed at laboratory of Pathology Division, Faculty of Veterinary Medicine, Cairo University. Whereas, cytological study was carried out at Central Laboratory, Faculty of Science, Ain Shams University.

\section{Experimental animals:}

A total of 16 pregnant Friesian cows aged 3.5 to 6.5 years, and had 2 to 4 parities. These cows were divided into two groups ( 8 cows each). The first group included cows with dry period more than 60 days (more than the optimum period). While the second group included cows with dry period less than 45 days (less than the optimum period).

\section{Management and feeding:}

Cows were housed loose in semi-shaded open yard throughout the experimental periods and fed on green Berseem (Trifolium alexandrinum) and concentrate mixture during December to end of April. While during November, May and June they fed on corn silage, Berseem hay and concentrate mixture. Also they fed rice straw ad libitum as a roughage allover the year. Feed was offered twice daily at 08:00 $\mathrm{h}$ and 16:00 $\mathrm{h}$. and drinking fresh water was available.

Cows were dried off by using abrupt cessation of milking method, when cow giving 1 to $2 \mathrm{Kg}$ /day. After the last milking, teats of each cow were washed and infused with antibiotics which help it to protect infections that may occur in early involution. 
The studied dry periods were divided into three phases; 1) Active involution phase (AI, the beginning of the dry period - 28 days after drying off). 2) Steady state involution phase (SSI, mid-dry period - its length depends on total length of the dry period). 3) Redevelopment and colostrogenesis phase (RC, the last of dry period - 28 days before parturition).

\section{Mammary tissue biopsies and preparations:}

Mammary tissue biopsies were taken from rear quarters once from each cow by surgical method during the experimental period and totals samples were taken as following, 4 samples were taken 7 days at $4 \mathrm{~h}$ after the milking before drying off, 4 samples were taken 14 days after drying off (the beginning of dry period), 2 samples were taken 35 days after drying off and also about 35 days before parturition (middry period), and 4 samples were taken about 14 days before parturition (at the last of dry period).

The biopsy sample was divided into two parts; the first was processed for light microscope technique, whereas the second part was applied for electron microscope technique for cytological study.

For histological studies, specimens were immediately fixed in $10 \%$ buffered formalin solution for 24 hours and washed by running tap water for 18-24 hours. Then, the fixed samples were dehyderated in ascending grades of alcohol, 60, 70, 80, 90 and $95 \%$ (one bath for each) and absolute alcohol (two baths) to remove water from the samples gradually. The dehyderated samples were placed in zylen for 8-10 hours. The samples were placed in three successive baths of melted paraffin wax (55$58^{\circ} \mathrm{C}$ ) for two hours each and thereafter placed in melted wax blocks. Then, the paraffin blocks were cut into thin sections of $5-10 \mu \mathrm{m}$ by microtome. Finally, the prepared sections were stained by heamatoxylin and eosin and mounted in canada balsam using the routine method according to Bancroft and Stevens (1990).

For ultastructural studies, specimens were placed in fresh 5\% cold glutaraldehyde and fixation was continued for five hours. Then washed in two changed of cold phosphate buffer for 1 hour. The fixed samples were dehydrated in cold ethanol 30 , 50, 70, 80 and 90\%. Embedding was carried out in epon 812 acetone mixture. The well infiltrated specimens were embedded in rubber boats filled with fresh epon 812 . Blocks were polymerized at $60^{\circ} \mathrm{C}$ for 24 hours. Semi-thin sections of $0.7 \mu \mathrm{m}$ thickness were cut with glass knives on the $6000 \mathrm{MT}$ RMC ultramicrotome. They were mounted on glass slides and stained with $25 \%$ toluidine blue. For the electron microscope preparations, thin sections were cut from a preselected area of the block provided by viewing a semi-thin section with a light microscope. Silver thin sections of 60 to $90 \mathrm{~nm}$, were prepared by diamond knife and collected on copper grids. These sections were stained with $5 \%$ uranyl acetate for 20 minutes. Uranyl acetate adding $0.5 \mathrm{gm}$ to $100 \mathrm{ml} \mathrm{30 \%}$ ethanol, mix well, filter and store in amber glass bottle in the dark. Thin sections were then stained in lead citrate. The later solution was prepared by adding $1.33 \mathrm{gm}$ lead acetate and $1.76 \mathrm{gm}$ sodium citrate to $30 \mathrm{ml}$ distilled water, shaking resultant suspension vigorously for 1 minute and allow standing for 30 minutes with intermittent shaking to ensure complete conversion of lead acetate. After 30 minutes, $8 \mathrm{ml}$ of $1 \mathrm{~N}$ sodium hydroxide (carbonate-free) was added and the solution was diluted. Dilute to $50 \mathrm{ml}$ with distilled water and mix by inversion. Grids were stained for 20 minutes. The sections were then examined photographically by a 
JEOL 1200 EXII transmission electron microscope using the routine method according to Hayat (1970) and Davis (1971).

\section{RESULTS AND DISCUSSION}

\section{End of lactation phase:}

Figure (1) generally, shows lactating tissue (7 days before drying off) for cows received long dry period. The alveolar lumen $(\mathrm{Lu})$ occupied most of the tissue area and small amounts of connective tissue (CT) area were seen between alveoli. While Figure (2) shows lactating tissue (7 days before drying off) for cows with short dry period. The proportion of interalveolar CT appeared to increase, while the alveolar luminal area decreased too.

Details of alveolar epithelial cells for cows received long dry period were cuboidal, the nucleus (N) was oval and basally located, tight junctions between cells were apparent, particularly near the apical ends of adjacent cells, and myoepithelial cells (My) were present at the basal side of secretory epithelial cells (Figure 3). Extensive rough endoplasmic reticulum (RER) was abundant parallel cisternae (Figure 4). The cells contained numerous secretory vacuoles (V) and fat droplets, a well-developed Golgi apparatus, and many mitochondria (M) scattered about the cytoplasm (Figure 5), all of which are indicative of synthetic activity for alveolar epithelial cell.

Details of alveolar epithelial cells for cows received short dry period were cuboidal and contained many small vacuoles in the apical half of the cell, the nucleus generally was located basally, and mononuclear leukocytes $(\mathrm{MnL})$ were observed between the basement membrane and the epithelial cells (Figure 6). Some vacuoles contained separate regions of protein and lipid, suggesting that the vacuoles may have arisen from coalescing of both fat droplets and secretory vesicles, coalescing of multiple secretory vesicles were observed, as was fusion of smaller vacuoles, perhaps leading to the formation of the large vacuoles (Figure 7). The large vacuoles did not appear to be surrounded by a continuous membrane; however, occasional vacuoles were observed with intact membranes. A well-developed many mitochondria (M) and microvilli (Mi) were prevalent at the apical surface of cells (Figure 8).

\section{Active involution phase:}

Figure (9) shows mammary tissue during active involution phase (day 14 after drying off and on day 57 before parturition) for cows receiving the long dry period. The proportion of interalveolar connective tissue (CT) appeared to increase throughout the active involution phase, while the alveolar luminal area (Lu) decreased compared to lactating tissue (Figure 1). Figure (10) shows mammary tissue in active involution phase (day 14 after drying off and on day 21 before parturition) for cows receiving short dry period. The proportion of interalveolar connective tissue (CT) was to increased, while the alveolar luminal (Lu) area was decreased compared to the mammary tissue for cows receiving long dry period in the same phase. 


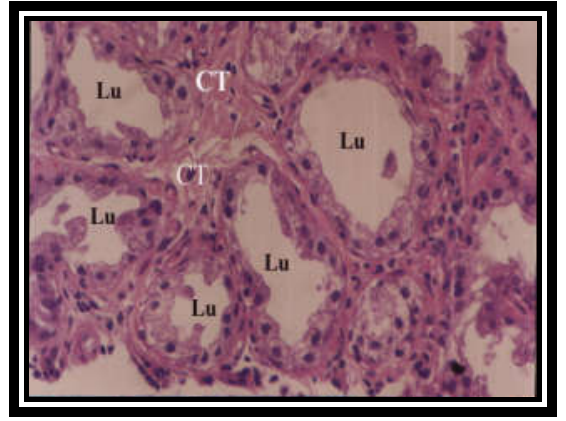

Figure 1: Light micrograph of lactating tissue for cows received the long dry period on day 7 before drying off and on day 69 before parturition, containing alveoli with large lumen (Lu) and small area of connective tissue (CT) between alveoli. Fully active epithelial cells are characterized by the basally located nuclei (N), and large cytoplasm. (X 500).

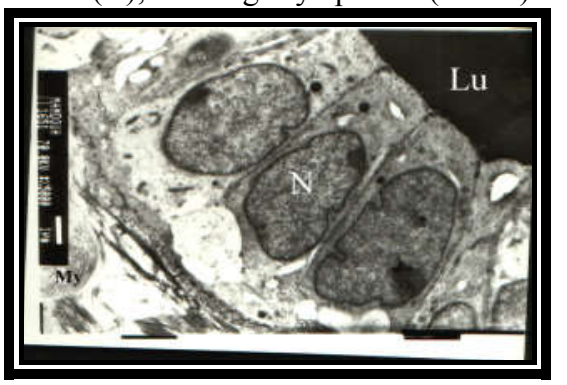

Figure 3: Electron micrograph of epithelial cells for cows received the long dry period on day 7 before drying off and on day 69 before parturition. The cells are cuboidal, the nucleus $(\mathrm{N})$ is oval and basally located, tight junctions between cells are apparent, particularly near the apical ends of adjacent cells, and myoepithelial cells (My) are present at the basal side of secretory epithelial cells. Lu = Lumen. (X 5000).

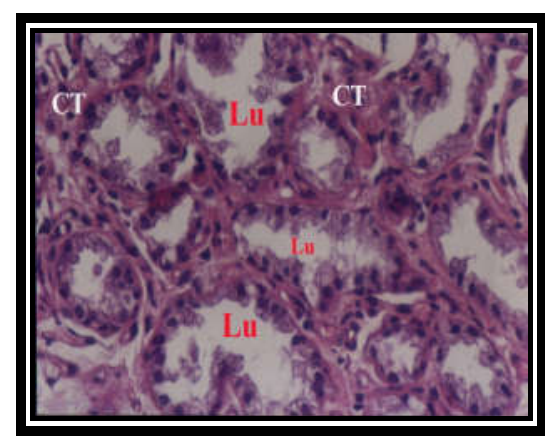

Figure 2: Light micrograph of lactating tissue for cows received the short dry period on day 7 before drying off and on day 37 before parturition. Large proportion of connective tissue (CT) area and small luminal area $(\mathrm{Lu})$ are clear. (X 500).

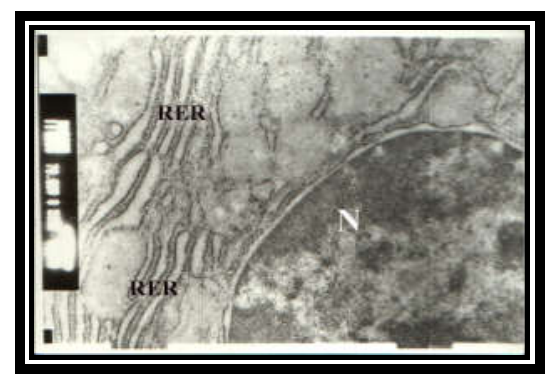

Figure 4: Electron micrograph of epithelial cells for cows received the long dry period on day 7 before drying off and on day 69 before parturition. Extensive rough endoplasmic reticulum (RER) is abundant parallel cisternae. $\mathrm{N}$ $=$ nucleus. (X 15000). 


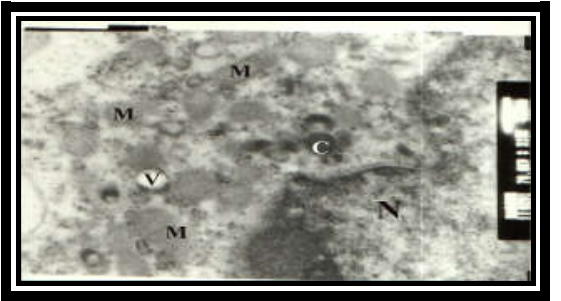

Figure 5: Electron micrograph of epithelial cells for cows received the long dry period on day 7 before drying off and on day 69 before parturition. The cells contained numerous casein micelles $(\mathrm{C})$, vacuoles $(\mathrm{V})$, and many mitochondria (M) scattered about the cytoplasm. $\mathrm{N}=$ nucleus. (X 15000).

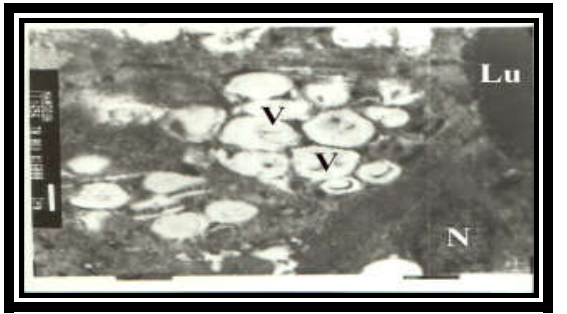

Figure 7: Electron micrograph of epithelial cells for cows received the short dry period on day 7 before drying off and on day 37 before parturition. The cells contained numerous secretory vacuoles $(\mathrm{V}) . \mathrm{Lu}=$ lumen. $\mathrm{N}=$ nucleus. (X 6000).

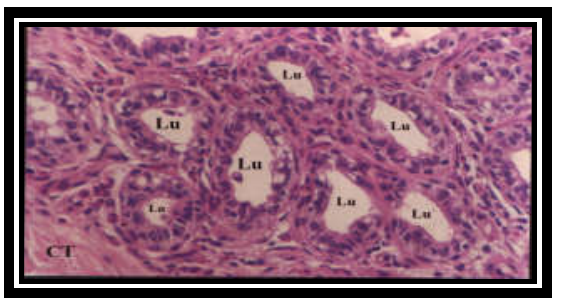

Figure 9: Light micrograph of mammary tissue for cows receiving the long dry period on day 14 after drying off and on day 57 before parturition. The proportion of interalveolar connective tissue (CT) is increased, while the alveolar luminal area $(\mathrm{Lu})$ is decreased. (X $500)$.

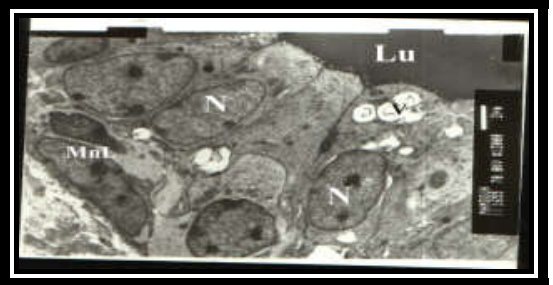

Figure 6: Electron micrograph of epithelial cells for cows received the short dry period on day 7 before drying off and on day 37 before parturition. The cells were cuboidal and contained many small vacuoles (V) in the apical half of the cell, the nucleus $(\mathrm{N})$ was located basally, and mononuclear leukocytes $(\mathrm{MnL})$ are observed between the basement membrane and the epithelial cells. $\mathrm{Lu}=$ Lumen. (X 3000).

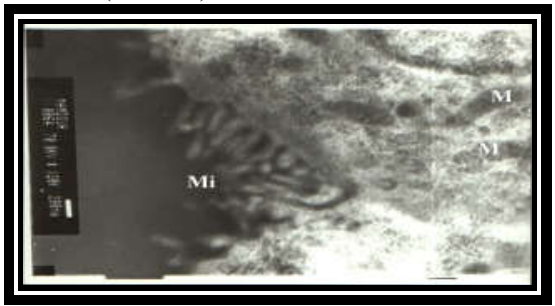

Figure 8: Electron micrograph of epithelial cells for cows received the short dry period on day 7 before drying off and on day 37 before parturition. A well-developed many mitochondria (M) and microvilli (Mi) are prevalent at the apical surface of cells. (X 20000).

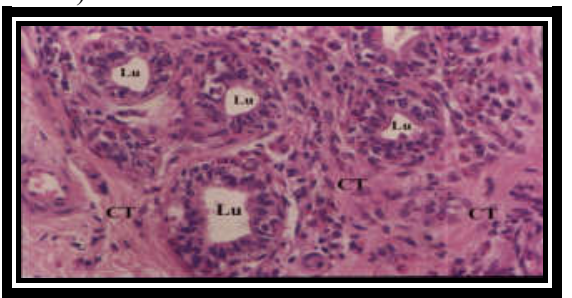

Figure 10: Light micrograph of mammary tissue for cows receiving the short dry period on day 14 after drying off and on day 21 before parturition. The proportion of interalveolar connective (CT) tissue increase, while the alveolar luminal area (Lu) is decreased compared to mammary tissue for cows receiving the long dry period in the same phase. (X 500). 
The ultrastructure of secretory epithelial cells for cows receiving the long dry period was markedly altered during the active involution phase. Large vacuoles had formed in the cytoplasm of alveolar epithelial cells, most vacuoles appeared to contain only lipid, few lysosomal structures were observed, mitochondria were present throughout this period, tight junctions always were present, mononuclear leukocytes were observed between the basement membrane and the epithelial cells (Figure 11). And cytoplasm had significantly fewer rough endoplasmic reticulum (RER) cisternae (Figure 12).

Alveolar epithelial cells during the active involution phase (day 14 after drying off and on day 21 before parturition) for cows receiving the short dry period showed the large vacuoles which occupied a major proportion of the intracellular space, often causing the cell to bulge into the alveolar lumen. Cytoplasm was compressed into a thin region around the vacuole with many mitochondria and other cellular organelles packed into a small area around the nucleus. The nucleus generally was located basally and was often misshapen by the presence of the large vacuoles. Some vacuoles contained separate regions of protein and lipid, suggesting that the vacuoles may have arisen from coalescing of both fat droplets and secretory vesicles. Coalescing of multiple secretory vesicles was observed, as was fusion of smaller vacuoles, perhaps leading to the formation of the large vacuoles (Figure 13). In Figure (14), the epithelial cells contained numerous mitochondria and some organized RER (albeit greatly reduced from active involution tissue for cows receiving the long dry period). Much cellular debris observed within the alveolar lumen (Figure 15).

\section{Steady state involution phase:}

Figure (16) shows mammary tissue in steady state involution phase (day 35 after drying off and on day 37 before parturition) for cows receiving the long dry period. The increased interalveolar space primarily was filled with fibrous connective tissue, although numerous cells were observed in that area. Connective tissue between alveoli had increased dramatically compared to active involution phase (Figure, 9). Some of the alveoli appeared as a mass of cells. General alveolar structure was intact.

The vacuoles remained in alveolar epithelial cells during that phase and appeared to be fat droplets. These fat droplets were frequently associated with several mitochondria (Figure 17). The cells had more highly convoluted nuclei than those observed in active involution phase (Figure 11) and "pale" cells. In Figure (18) epithelial cells contained numerous mitochondria and some organized RER (albeit greatly reduced from active involution tissue), lysosomes were observed frequently within the cytoplasm.

\section{Redevelopment and colostrogenesis phase:}

Figure (19) shows mammary tissue in redevelopment and colostrogenesis phase (day 15 before parturition) for cows receiving the long dry period. The proportion of the alveolar luminal area was increased throughout this period, while interalveolar connective tissue area was decreased. Also, Figure (20) shows mammary tissue in redevelopment and colostrogenesis phase (day 13 before parturition) for cows receiving the short dry period which revealed that the proportion of alveolar luminal area was increased throughout this period, while interalveolar connective tissue area was decreased. 


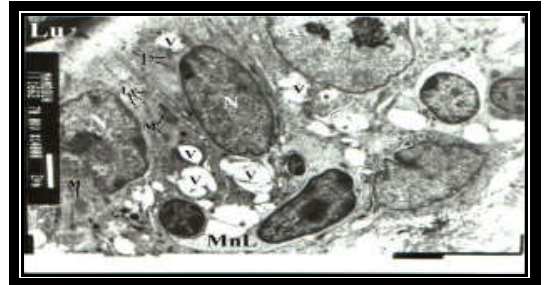

Figure 11: Electron micrograph of epithelial cells for cows receiving the long dry period on day 14 after drying off and on day 57 before parturition. Large vacuoles (V) are formed in the cytoplasm, few lysosomal (Ly) structures are observed, mitochondria (M) are present, mononuclear leukocytes $(\mathrm{MnL})$ are observed between the basement membrane and the epithelial cells. $\mathrm{Lu}=$ Lumen. $\mathrm{N}=$ nucleus. (X 4000).

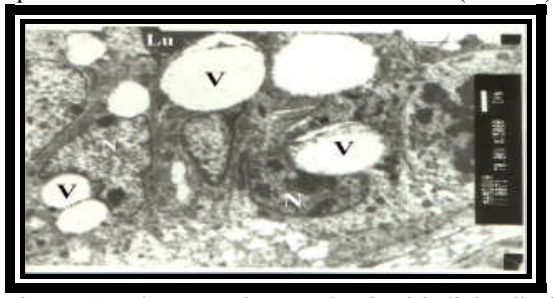

Figure 13: Electron micrograph of epithelial cells for cows receiving the short dry period on day 14 after drying off and on day 21 before parturition. The large vacuoles (V) occupy a major proportion of the intracellular space. Cytoplasm is compressed into a thin region around the vacuole with many mitochondria and other cellular organelles packed into a small area around the nucleus. The nucleus $(\mathrm{N})$ is often misshapen by the presence of the large vacuoles. $\mathrm{Lu}=$ Lumen. $(\mathrm{X} 5000)$

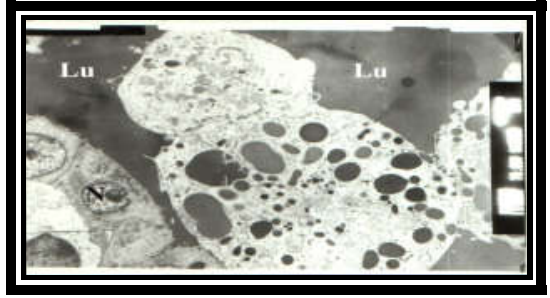

Figure 15: Electron micrograph of large cellula debris observed within the alveolar lumen for cows receiving the short dry period on day 14 after drying off and on day 21 before parturition. (X 5000)

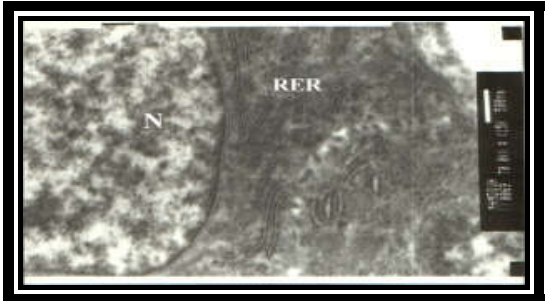

Figure 12: Electron micrograph of epithelial cells for cows receiving the long dry period on day 14 after drying off and on day 57 before parturition. Cytoplasm has significantly fewer rough endoplasmic reticulum (RER) cisternae. $\mathrm{N}=$ nucleus. (X 15000).

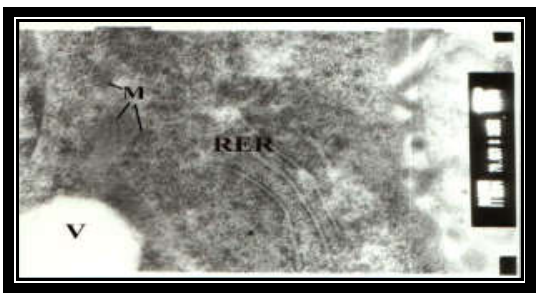

Figure 14: Electron micrograph of epithelial cells for cows receiving the short dry period on day 14 after drying off and on day 21 before parturition. The cells contained numerous mitochondria $(\mathrm{M})$ and some organized rough endoplasmic reticulum (RER). V = vacuoles. (X 15000).

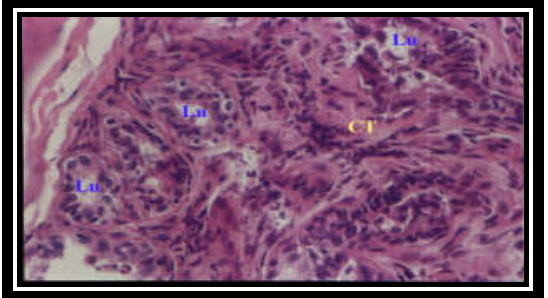

Figure 16: Light micrograph of mammary tissue for cows receiving the long dry period on day 35 after drying off and on day 37 before parturition. The increased interalveolar space primarily is filled with fibrous connective tissue (CT). Some of the alveoli appeared as a mass of cells. General alveolar structure is intact. $\mathrm{Lu}=$ Lumen. (X 500). 


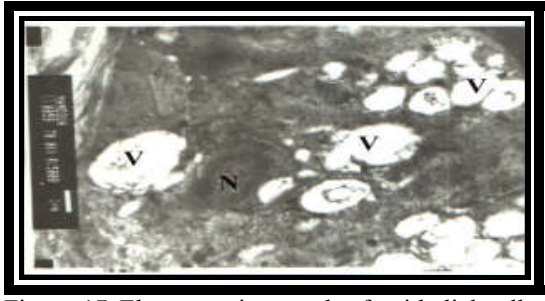

Figure 17: Electron micrograph of epithelial cells for cows receiving the long dry period on day 35 after drying off and on day 37 before parturition. The vacuoles (V) remained in alveolar epithelial cells during that phase and appeared to be fat droplets. These fat droplets are frequently associated with several mitochondria. The cells had more highly convoluted nuclei $(\mathrm{N})$ than those observed in active involution phase and "pale" cells. (X 5000).

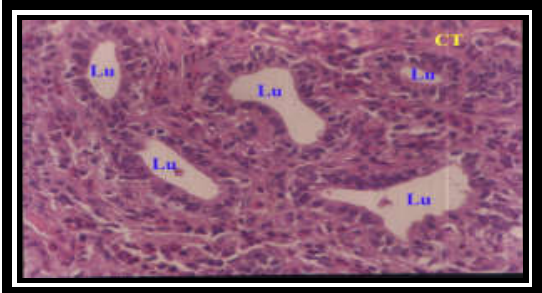

Figure 19: Light micrograph of mammary tissue for cows receiving the long dry period on day 53 after drying off and on day 15 before parturition. The proportion of alveolar luminal area $(\mathrm{Lu})$ is increased throughout this period, while interalveolar connective tissue (CT) area decreased. (X 500).

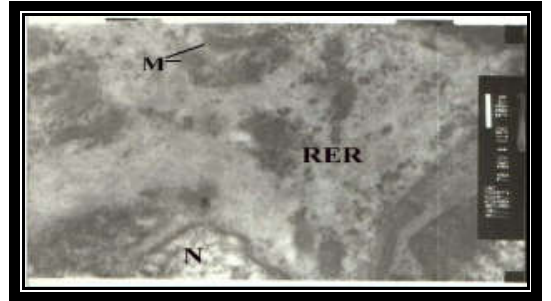

Figure 18: Electron micrograph of epithelial cells for cows receiving the long dry period on day 35 after drying off and on day 37 before parturition. The cells contained numerous mitochondria $(\mathrm{M})$ and some organized rough endoplasmic reticulum (RER). $\mathrm{N}=$ nucleus. $(\mathrm{X} 15000)$.

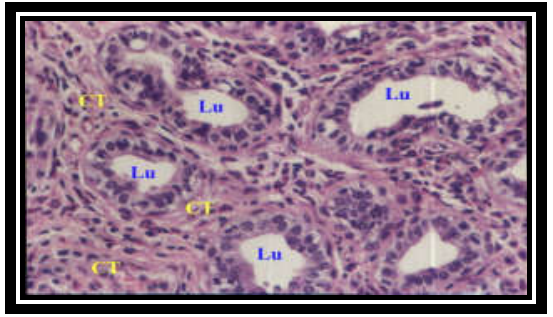

Figure 20: Light micrograph of mammary tissue for cows receiving the short dry period on day 19 after drying off and on day 13 before parturition. The proportion of alveolar luminal area $(\mathrm{Lu})$ is increased throughout this period, while interalveolar connective tissue (CT) area also decreased. (X 500).

Alveolar epithelial cells during redevelopment and colostrogenesis phase for cows receiving the long dry period and at the same days before parturition began to have secretory activity, with appearance of small fat droplets and vesicles containing casein micelles that accumulated under the apical plasma membrane, Golgi apparatus and numerous mitochondna throughout the cytoplasm (Figure 21). Also, epithelial cells had abundant and parallel RER in the basal region (Figure 22).

Alveolar epithelial cells in redevelopment and colostrogenesis phase for cows receiving short dry period on day 19 after drying off and on day 13 before parturition (Figure 23), shows that, the nuclei of some epithelial cells took on a smooth ovoid shape, and microvilli became evident along the apical surface. Also, epithelial cells had Golgi apparatus, numerous mitochondna, and abundant RER throughout the cytoplasm.

Morphologic changes during involution indicated marked shifts in the secretory activity of the gland during the active involution phase of the nonlactating period, followed by more gradual changes as calving approached. During the active involution phase, secretory activity of mammary epithelium was decreased, as 
evidenced by a reduction in alveolar luminal area with a concomitant increase in connective tissue area. Luminal spaces decreased when secretion no longer displaced the alveolar area. Once milk synthesis ceased and mammary fluid was resorbed, connective tissue areas expanded proportionately to compensate the reduced alveolar luminal area. Bovine mammary tissue appeared to be exhibiting a similar trend (Sordillo and Nickerson, 1988; Hurley 1989; and Capuco et al., 1997).

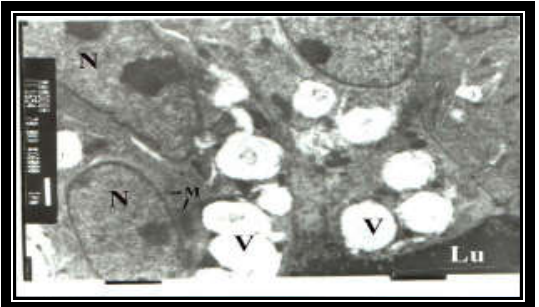

Figure 21: Electron micrograph of epithelial cells for cows receiving the long dry period on day 53 after drying off and on day 15 before parturition. The vesicles (V) accumulated under the apical plasma membrane, Golgi apparatus and numerous mitochondna (M) throughout the cytoplasm. $\mathrm{N}=$ nucleus (X 6000)

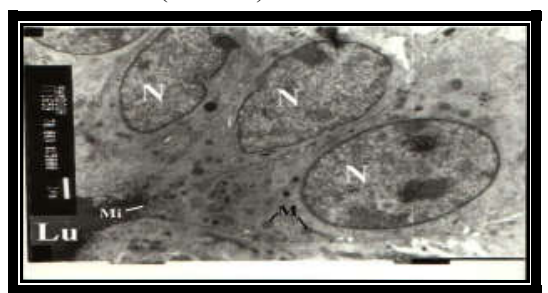

Figure 23: Electron micrograph of epithelial cells for cows receiving the short dry period on day 19 after drying off and on day 13 before parturition. The nuclei $(\mathrm{N})$ of some epithelial cells took on a smooth ovoid shape, and microvilli (Mi) became evident along the apical surface. Epithelial cells had Golgi apparatus, numerous mitochondna $(\mathrm{M})$, and abundant RER throughout the cytoplasm. (X $5000)$.

Cytoplasmic organelles declined in the involuting cells, particularly those involved in the extensive milk protein synthesis and secretion function of the lactating cell, such as the RER, Golgi apparatus, and secretory vesicles. The remaining RER was more sparse.

Despite the apparent breakdown of the protein synthesis and secretion pathway associated with milk proteins, the involuting epithelial cells maintained intact cellular 
organelles involved in metabolic and secretory function. Ribosomes and segments of RER were present at all stages, as were mitochondria and microvilli. Appearance of cells was markedly altered from that of epithelial cells in lactating tissue, but nonetheless the epithelial cells seemed to be functioning, in keeping with previous findings (Holst et al., 1987; Sordillo \& Nickerson, 1988; and Hurley, 1989).

The alveolar epithelial cells in that nonlactating state appear to be capable of metabolic activity. Because of the remaining intact structures after the previous lactation, a fairly short time may be required to redevelop a structurally complete gland that is prepared for lactogenesis.

Invading macrophages have been implicated in removal of luminal milk fat globules in involuting mammary tissue and also may be involved in removal of cellular debris. The structure of alveoli at steady state involution phase (light microscope level) resembled the solid mass of cells. The morphology of bovine mammary tissue and the composition of mammary secretions remain relatively constant during steady state involution (Oliver and Bushe, 1987; Sordillo, 1987; and Oliver \& Sordillo, 1989).

In contrast with rodents, the involution of bovine mammary tissue does not involve extensive detachment of mammary epithelial cells from the basement membrane with their subsequent sloughing into the alveolar lumina, in keeping with previous findings (Hurley, 1989).

During the redevelopment and colostrogenesis phase, increased synthetic and secretory activity was apparent by increase areas of epithelium and lumen and a decrease area of connective tissue. Expansion of alveolar lumina area resulted in a concomitant compression of surrounding connective tissue area. As parturition approached, fully active cells also became more numerous, as nonactive cells decreased. The cell cytoplasm contained abundant RER, with polarized and parallel cisternae, well-developed Golgi apparatus, and numerous mitochondria, the typical morphologic features indicative of milk synthesis and secretion. Sordillo and Nickerson (1988) reported similar changes in the Jersey cows mammary glands.

Although the progression of ultrastructural changes in alveolar epithelial cells was consistent between the cows receiving the long dry period and those receiving the short dry period, suggested that the rate at which this progression occurred was faster in cows receiving the short dry periods.

Ultrastructural changes of cow mammary tissue suggest that a mammary involution as it relates to the epithelia, occurs as an organized and controlled process that apparently leads to minor loss of epithelial cells. As well as, a dry period is important for replacing senescent mammary epithelial cells and increasing the epithelial component of the gland prior to the next lactation.

\section{REFERENCES}

Akers, R. M., W. E. Beal, T. B. McFadden and A. V. Capuco, 1990. Morphometric analysis of involuting bovine mammary tissue after 21 or 42 days on nonsuckling. J. Anim. Sci., 68: 3604-3613.

Bancroft, J. D. and A. Stevens, 1990. Theory and Practice of Histological Techniques. Churchill Livingstone, Edinberg, London. 
Capuco, A.V., R.M. Akers and J.J. Smith, 1997. Mammary growth in Holstein cows during the dry period: quantification of nucleic acids and histology. J. Dairy Sci., $80: 477-487$.

Davis, D., 1971. Histopathologic Technic and Practical Histochernistry. Mc GrawHill, New York 3rd ed., USA, p. 112.

Hayat, M., 1970. Principles and Techniques of Electron Microscopy. Harper and Row, New York. 1st ed.,USA, p. 343.

Holst, B.D., W.L. Hurley and D. R. Nelson, 1987. Involution of the bovine mammary gland: histological and ultrastructural changes. J. Dairy Sci., 70:935-944.

Hurley, W.L., 1989. Mammary gland function during involution. J. Dairy Sci., 72:1637-1646.

Oliver, S. P. and L.M. Sordillo, 1989. Approaches to the manipulation of mammary involution. J. Dairy Sci., 72:1647-1664.

Oliver, S. P. and T. Bushe, 1987. Growth inhibition of Escherichia coli and Klebsiella pneumoniae during involution of the bovine mammary gland: relation to secretion composition. Am. J. Vet. Res., 48: 1669.

Sordillo, L.M., 1987. Physiological aspects of bovine mammary involution: a biochemical and morphological investigation. Ph. D. Diss., Louisiana State Univ., Baton Rouge, USA.

Sordillo, L.M. and S.C. Nickerson, 1988. Morphologic changes in the bovine mammary gland during involution and lactogenesis. Am. J. Vet. Res., 49:11121120. 


\section{الغدة اللبنية في الأبقار خلال فترة الجفاف: ا ــ التغيرات الهستولوجية والسيتولوجية}

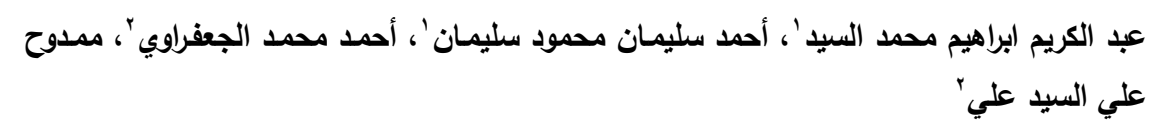

ا - قسم الإنتاج الحيوانس، كلية الزراعة، جامعة بنها، r - معهد بحوث الإنتاج الحيوانسي، مككز البحوث

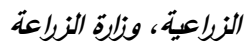

استخدم في هذه الدراسة 17 بقرة فريزيان عشار قسمت طبقاً لطول فترة الجفاف إلي مجموعتين. المجموعة الاولي (تتمل ^ بقرات) وهي التي لها فترة جفاف اكثر من ـ ج يوماً بينما المجموعة الثانية (1 بقرات ايضا) وهي التي لها فترة جفاف أقل من 0؛ يوماً. وذلك لنقيم وتفسير التغيرات الهستولوجية والسيتولوجية التي تحدث في نسيج الغدة اللبنية خلال المراحل المختلفة لفترة الجفاف لنلك الابقار ـ ولتحديد تأثير هذه التغيرات علي نشاط الغدة خلال فترة ما قبل الولادة.

أشارت التغيرات الهستولوجية خلال مرحلة الضمور النشط لفترة الجفاف إلي انخفاض النشاط الافرازي للغدة خلال تلك المرحلة و يتضح ذلك من خلال انخفاض مساحة التجويف الحويصلي وزيادة مساحة النسيج الضام للغدة في نفس الوقت. انخفضت كمية العضيات السيتوبلازمية في الخلايا الضامرة وخاصة المسئولة عن نخليق وافراز بروتينات اللبن مثل الشبكة الاندوبلازميـة والريبوسومات واجسام جولجي والحويصلات الافرازيـة. علي الرغم من التوقف الظاهري للنشاط التمثيلي للخلايا الطلائية الضامرة فقد حافظت علي عضياتها التي تشترك في التخليق والافراز سليمة ويتضح ذلك من خلال وجود الثبكة الاندوبلازمية والميتوكوندريا والخميلات خلدل جميع فئي مراحل فترة الجفاف المختلفة. تغزو كريات الدم البيضاء نسيج الغدة خلال مرحلة الضمور وذللك لإزالة حبيبات

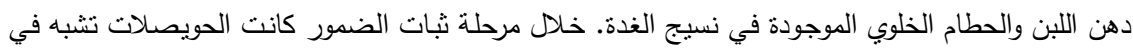
التزكيب الكتلة الصلبة من الخلايـا. بينما كان التركيب الهستولوجي لنسيج الغدة خـلال تلك المرحلة وتركيب

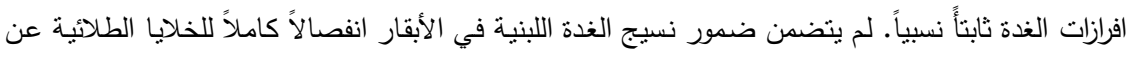
الغشاء القاعدي كما يحدث في القوارض. خلال مرحلة إعادة تطور الغدة - تخليق السرسوب يزداد النشاط التخليقي والافرازي للغدة ويظهر ذلك من خلال زيادة مساحة الخلايا الطلائية والتجاويف الحويصلية مما يؤدي إلي الضغط علي مساحة النسيج الضام والتي تنخفض بالتالي كلما إقتربت الولادة. وتصبح الخلايـا الطلائية الافرازيـة نشطة ويتضح ذلك من خـلال احتواء الخلايـا علي كميات كبيرة من الشبكة الاندوبلازميـة وأجسام

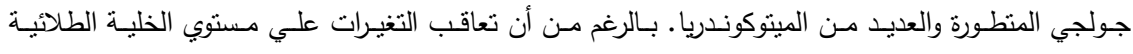
الحويصلية كان ثابتاً لكل من الأبقار التي لها فترة جفاف طويلة وفترة جفاف قصيرة إلا أن معدل حدوثها كان

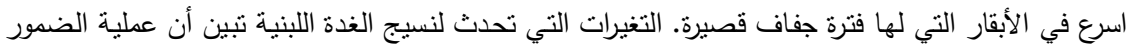
تحدث بانتظام وبطريقة محكمة وتؤدي إلي فقد بسيط في الخلايا الطلائية كما أن فترة الجفاف مهمة لإستبدال الخلايا الطلائية المسنة بأخري جديدة وزيادة المكون الطلائي للغدة قبل موسم الحليب التالي. 